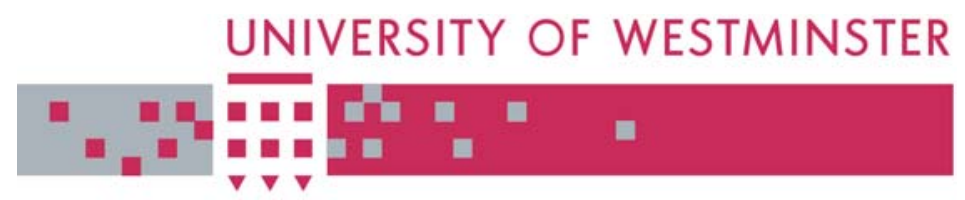

WestminsterResearch

http://www.wmin.ac.uk/westminsterresearch

\title{
Developing communities of innovation by identifying innovation champions.
}

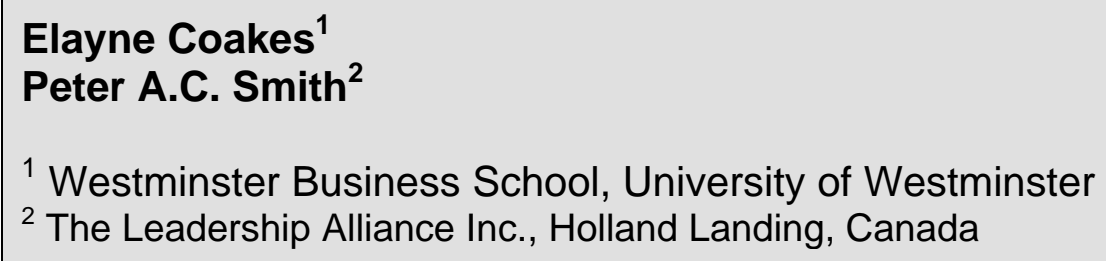

${ }^{1}$ Westminster Business School, University of Westminster

${ }^{2}$ The Leadership Alliance Inc., Holland Landing, Canada

This is an electronic, author-formatted version of an article published in The Learning Organization, 14 (1). pp. 74-85, 2007. The definitive version in The Learning Organization is available online at:

\section{http://dx.doi.org/10.1108/09696470710718366}

The WestminsterResearch online digital archive at the University of Westminster aims to make the research output of the University available to a wider audience. Copyright and Moral Rights remain with the authors and/or copyright owners.

Users are permitted to download and/or print one copy for non-commercial private study or research. Further distribution and any use of material from within this archive for profit-making enterprises or for commercial gain is strictly forbidden.

Whilst further distribution of specific materials from within this archive is forbidden, you may freely distribute the URL of the University of Westminster Eprints (http://www.wmin.ac.uk/westminsterresearch).

In case of abuse or copyright appearing without permission e-mail wattsn@wmin.ac.uk. 
Developing Communities of Innovation by Identifying Innovation Champions

\author{
25/07/2006 \\ Elayne Coakes \\ Westminster Business School
}

\&

Peter Smith

The Leadership Alliance Inc 


\title{
Developing Communities of Innovation by Identifying Innovation Champions
}

\section{Conceptual Paper}

\begin{abstract}
Purpose - Conceptual paper proposes that a form of CoP; a Community of Innovation (CoInv) is the best support for sustainable innovation and outlines a method for identifying champions of innovation in organisation.
\end{abstract}

Approach - Draws on extant research to argue that innovation is facilitated and supported by innovation champions, who have most influence outside traditional organisational structures when they are members of a close-knit community; a CoInv. A potential method for identification of champions of innovation is highlighted.

Findings - Innovation champions are special people, with particular personality types and psychological profiles. In order to succeed in championing innovations in organisations they need both procedural and resource support, and social and cognitive support. The influence of innovation champions comes through social contacts, multiplied through the communities in which they participate, through the genuine esteem in which they are held. Developing CoInv around such champions makes practical sense for organisations.

The value of this paper and practical implications - Identifying champions of innovation will permit a CoInv to form that links social networks and transcends organisational internal boundaries and forming such a community will potentially trigger more successfully supported innovations. 


\section{Developing Communities of Innovation by Identifying Innovation Champions}

\section{Introduction}

Why do organisations innovate? The answer seems to lay in the concept of "right to market" (Koudal \& Coleman, 2005). This means introducing the right products at the right time in the right markets with the right supply chain, and then continually updating, optimising, and retiring them as necessary. We submit that in today's turbulent environments the capability for sustainable corporate entrepreneurship and innovation is a critical pre-requisite for successfully achieving "best fit”, near-term competitive advantage, and long-term viability.

Based on practical experiences of consultancy and theoretical arguments, this paper proposes that a form of Communities of Practice (CoPs) that we term Communities of Innovation (CoInv) are the best support for sustainable innovation, and that the introduction and support of CoInv are a critical element of the corporate entrepreneurship process. Although speculative at present, we believe that the published network visualization study briefly reviewed here demonstrates practical potential for identifying champions of innovation; the individuals in an organization who have the appropriate characteristics and motivation to successfully form a CoInv network and that forming such a community will potentially trigger more innovations.

\section{Innovation and the Role of Entrepreneurship}

Innovation may be defined as the process of bringing new problem-solving ideas into use (Amabile 1988; Glynn 1996; Kanter 1983). The emphasis in this quote is on the phrase into use, for Tidd (2001) argues that just the invention of new knowledge is insufficient and Sullivan (1998), and Teece (1998), say that innovation has only occurred if the new knowledge has been implemented or commercialised in some way. A number of authors echo this view (Pinchot, 1985; Thornberry, 2001; Zahra, 1985) asserting that without the presence of some form of entrepreneurial activity to exploit opportunities as they arise 
within organisations, innovation remains little more than an aspirational destination, rather than a tangible one. Consistent with these views, we follow McFadzean et al (2005) in defining entrepreneurship as the promotion of innovation in an uncertain environment, and innovation as the process that through its products, services, and processes adds value and novelty to the organization, its suppliers and customers. McFadzean et al (2005) quote Amit et al (1993; pp 816) saying that the two concepts should be linked together, and McFadzean et al (2005) and Shaw et al (2005) make a strong case for considering these concepts systemically.

These interpretations imply that entrepreneurship and innovation both add value, and that it is the corporate entrepreneur's role to manage the innovation process such that it will lead to sustained competitive advantage and organisational viability. Authors such as Adaman and Devine (2002) suggest that entrepreneurship is founded in social interaction occurring within and outside the organisation, and Churchman (1971) proposes that knowledge sharing processes may effect the creation of new potentials for action. In this paper we advance the notion that a critical aspect of the entrepreneurial role is the development of knowledge sharing communities where innovation may be incubated and entrepreneurship facilitated. McFadzean et al (2005; pp. 352) define such corporate entrepreneurship as The effort of promoting innovation from an internal organisational perspective, through the assessment of potential new opportunities, alignment of resources, exploitation and commercialisation of said opportunities. The characteristics of such communities are discussed in the next section.

\section{Communities for Innovation}

Successful organisational innovation must be based (according to innovation theory, see Glynn 1996) in co-ordination mechanisms that support the problem-solving efforts of the organisation's Human Capital, and the dynamic processes of sense making within organisations (Drazin et al, 1999). Leonard-Barton and Sensiper (1998) argue that innovation depends upon the individual and collective expertise of employees, and innovation is characterised by an iterative process of people working together building on 
the creative ideas of one another. Numerous examples are provided by Hargadon (2003) based on ten years of research demonstrating that revolutionary innovations result from the creative combining of ideas, people and objects rather than flashes of brilliance by lone inventors. Stacey (2001) places self-organising human interaction, with its ability for emergent creativity, at the centre of the knowledge creating process, and suggests that organisational knowledge depends on the qualities of the relationships between people. Glynn (1996) proposes that organisational intelligence is context specific and different from the aggregation of individual intelligence (Nahapiet and Ghoshal, 1998).

The generation of new ideas that activates innovation is facilitated by diversity and breadth of experience, including experts who have a great deal of contact with other experts in the fields; links to users; and links to 'outsiders' (Moss Kanter 1988). Communities, it is therefore argued, are one of the supporting organisational forms for innovation. Creativity often springs up at the boundaries of disciplines and specialties, so innovative communities will work through collaboration with other communities, organizations, and also communities in other organisations - inter-and intraorganisationally. Communities are the place for developing new practices, new services and new products. In the next section the notion of communities of innovation (CoInv) is advanced; these CoInv are a special case of the more general communities of practice (CoPs)

\section{Communities of Practice and Communities of Innovation}

Given that community socialisation processes are critical to innovation and entrepreneurship, and that it is prudent to treat these processes systemically, CoPs (Communities of Practice) would seem to offer a promising practical vehicle for their eventuation. Brown and Duguid's (1991) study of CoPs explains how shared learning is entrenched in complex, collaborative social practices, and many current authorities propose that CoPs provide an valuable framework for inter-agent context specific knowledge sharing, sense making, and knowledge creation (Coakes \& Clarke, 2005). Wenger et al (2002; p. 4) have provided a widely accepted definition of CoPs as Groups of people who 
share a concern, a set of problems, or a passion about a topic, and who deepen their knowledge and expertise in this area by interacting on an ongoing basis. These authors add that “These people don't necessarily work together every day, but they meet because they find value in their interactions” (ibid; pp. 4).

In other words, CoPs are knowledge creation and sharing networks (Cross et al 2001) and are comprised of members of many social networks naturally (Schenkel et al 2001). Lesser and Storck (2001) say that we must think of a CoP as an engine for the development of social capital. They argue that the social capital resident in communities of practice leads to behavioral changes, which in turn positively influence business performance. (online). Social capital, in particular, they argue shortens the learning curve, increases responsiveness to customer experiences, reduces rework and prevents reinvention, and also increases innovation. Wenger (1998) indeed argues that a CoP could be considered as the node of strong ties in a social network. As Wenger (2001 p1) says: Communities of Practice are Focused on a domain of knowledge and over time accumulate expertise in this domain. They develop their shared practice by interacting around problems, solutions, and insights, and building a common store of knowledge. Assimakopoulos and Yan (2005) further argue that the common practice of a community gives them a knowledge domain, a shared identity and cohesiveness to sustain interactions over time (p475). Indeed, one of the functions of CoPs may be the enculturation, or socialisation of its members into a community’s “approved” mindset. Successful membership of a community implies support for the culture of that community - a shared vision -, and its over-riding ethical and moral standpoint on particular activities or actions - a belief in their values above all others. Human Capital contains the intellectual capability to create and innovate through the mixing of skills with knowledge and this innovation occurs within the context of organisational culture and its shared values, beliefs, expectations and attitudes.

Communities of Innovation (CoInv) we propose, are a form of CoPs that are very specifically dedicated to the support of innovation, and their formation and sustainability are the responsibility of those individuals charged with organizational entrepreneurship. 
CoInv are an important new concept that this paper theorises can be formed from champions of innovation and their social networks, to provide safe places for the creation and support of innovatory ideas. They are safe because they should be considered by management as subject to the same practices as other Communities of Practice. As an example at Xerox, communities build their own agenda by polling members about what they want to learn, ask members at the end of meetings what they have learnt, and record post-meeting the key messages for the larger community. This ensures that knowledge sharing becomes part of the community's processes and cultural norms - which may operate outside the formal organisational structure. Indeed Xerox gives communities enough autonomy to operate independently - the community's facilitator's prime commitment is to the group rather than Xerox and a 'zone of safety' is established for candid (and unwelcome?) discussions (Lehaney et al 2004).

As these CoInv will be comprised of those that actively champion new ideas and those who wish to be associated with them and to develop innovation, support for new ideas is automatic.

\section{Champions of Innovation}

Howell (2005) states that $90 \%$ of raw ideas never go beyond the idea-generator's desk. Only $3 \%$ of the remaining $10 \%$ obtain sufficient backing to become projects with less than $1 \%$ being commercially launched. She argues that one reason for the high failure rate of new ideas is their failure to attract a champion. Dedicated champions, Howell states, are pivotal to innovation success and thus must be supported in their efforts and integrated into the mainstream of organisational activity. Glynn (1996) points to the existence of "innovation champions" who have the social, political or interpersonal knowledge to influence the acceptance of innovative change.

Championing innovation must become a norm in organisations and not an episodic event that relies on happenstance and a strong-minded individual expending large amounts of 
effort. Innovation championship and the development of such champions fall naturally, we would argue, into the activities and remit of CoPs and more especially CoInvs.

The primary role of innovation champions in promoting innovation is embodied in the framework for innovation diffusion developed by Rogers (1995) based on more than twenty years of research. Rogers defines innovation diffusion as the process by which an innovation is communicated through certain communication channels over time among the members of a social system.

Rogers proposes that the innovation diffusion process takes place in five stages:

1. Knowledge is the stage where a potential adopter learns about the existence of an innovation and gains some understanding of it.

2. Persuasion is the stage where a favourable or unfavourable attitude towards an innovation is formed.

3. Decision is the stage where activities are undertaken which lead to the adoption or rejection of an innovation.

4. Implementation is the stage where an innovation is actually put to use.

5. Confirmation is the stage of reinforcement for an adoption decision which has already been taken.

Information about the existence of an innovation will be of interest to potential adopters in the early stages of the innovation-decision process, and evaluative knowledge is mainly sought in the persuasion and decision stages e.g. the relative advantage of the innovation over, and its compatibility with, existing conditions; its ease of understanding; whether it can be easily piloted; and whether examples can be viewed elsewhere (Kautz \& Larsen, 2000). This information is essential for reducing uncertainty about an innovation's consequences, and is most often sought from trusted peers. Rogers also indicates that interpersonal and local communications are relatively more important at the persuasion stage. 
Rogers emphasizes innovativeness as another important aspect of the process. This is the extent to which an individual is relatively quicker in adopting an innovation than others. Rogers proposes five categories of innovativeness:

1. Innovators who are gate keepers in the flow of new ideas into a social system;

2. Early adopters that decrease uncertainty about a new idea by adopting it and by then conveying a subjective evaluation to near-peers;

3. The early majority that follow in adopting an innovation and who through their position between the early and the late adopters are important links for further diffusion;

4. The late majority that according to Kautz \& Larsen (2000) often have scarce resources which means that almost all of the uncertainty about a new idea has to be removed before they adopt;

5. Laggards that are behind, extremely cautions concerning awareness knowledge, and may never adopt the innovation.

About $17 \%$ of CoInv community members (categories 1 and 2) may be expected to act as innovation champions. About 83\% of community members (categories 3 through 5) will explore and rely on their advice. Each sub-group category of the overall community shares knowledge with the sub-group category that follows it, and each in their turn serves to reduce the risk of adopting the knowledge into the following individuals' personal knowledge base. In a sense innovation champions are catalysts or inhibitors for intermittent or ongoing knowledge sharing efforts. In most mature organizations these champions through their ongoing relationships will be well aware of who falls within the various categories, and will as a matter of course seek to share knowledge with pragmatists. This is not an insignificant factor, since without this insight, Murphy's Law almost certainly ensures that opinion leaders trying to share innovation-related knowledge will meet up with laggards, and face a barrage of "Yes, BUT ...." responses.

Innovation champions are active in supporting innovation and seeking out opportunities, but they need to be encouraged and motivated by management. Howell and Higgins (1990) 
say that without champions organisations may have a lot of ideas but few tangible innovations. The challenge facing management is to identify and effectively manage existing champions and to nurture potential champions (p55). Parker and Axtell (2001); Howell and Bois (2004) say that in order to motivate others to innovate, champions need to take multiple perspectives and to work collaboratively with others, Howell and Bois extending this collaborative work into the field of idea generation. Champions naturally have a range of networks in which they participate and may be characterised as renaissance people (Howell 2005) with a large variety of interests and a diversity of activities. They tend to have had a long tenure in the organisation (Howell and Higgins 1990) with experience in many divisions and locations, and an in-depth knowledge of the industry.

Van de Ven (1986) says that one of the key issues for organisations is gaining appreciation of ideas, needs and opportunities for innovations. A 1996 study (Melcrum 2006 quoting Business Horizons) of 150 major US firms found that innovative companies had a profit growth that was four times that of non-innovative companies. The presence of innovation champions makes a decisive contribution to the innovation by actively and enthusiastically promoting its progress (Archilladelis et al 1971 p14), and a number of research projects have correlated the presence of such champions with successful innovations (Beath, 1991; Beatty \& Gordon, 1991; Holbeck, 1990). They tend to emerge informally in an organisation (Schön 1965; Tushman and Nadler 1986) which makes it difficult to routinely identify them. Some authors see these champions as transformational leaders who play a key role in innovations (Stata 1989, Tushman and Nadler 1986) by bringing together the people, and promoting vision and trust. Oberg (1972) says that transformational leadership is closely linked to the innovative process in organisations and that the transformational leader espouses values that are different from the organisational norm - they must thus have charisma. Howell and Higgins (1990) go further and link transformational leadership to champions hypothesising that champions will exhibit transformational leader behaviours, that is, charisma, inspiration, intellectual stimulation and individualized consideration (p321). Such charismatic leaders exercise extensive influence over the orientations of others (Etzioni 1961) and relate their mission and vision to the values and ideals of the organisational members, and the organisational culture. They will engage in symbolic 
actions through story telling (Lagace 2005 quoting Podolny, Khurana \& Hill-Popper), and will thus provide a vision for the community. Other important qualities of innovation champions that have been identified (Jenssen \& Jorgensen 2004) include the ability to take risks combined with a diplomatic talent (Chakrabarti \& Hauschildt, 1989); strong advocation and promotion ( Beath, 1991) with the ability to overcome opposition (Markham, 1998); and an ability to navigate through the social and political organisational environment (Day, 1994).

Mumford et al (2002) question the value of charisma and transformational leadership of creative people, as a leader's vision may prevent creative people from forming unique ideas and pursuing their own vision of the work (Mumford and Licuanan 2004). Again, here we would argue is where a CoInv would support the innovation process more effectively, as leaders would only emerge by consensus and these communities would naturally be involved in a multiplicity of innovatory ideas, rather than just that promoted by a solitary leader. Krause (2004), Mumford et al (2002) found that in relation to innovation leadership, autonomy and the exercise of influence through expertise were of particular value and thus social and organisational styles influence creative behaviour (Mumford and Licuanan 2004).

Howell (2005) has identified six crucial things that champions require from the workplace: to work within an innovative environment; to work with other innovators; to be challenged and to learn; to be (socially) connected within and without the organisation; to be recognised for their work; and to work for management that supports their activities. As previously stated, innovation champions already have extensive social networks in place and the challenge to the organisation and those charged with entrepreneurship is to transform these networks into communities of innovation. Once a CoInv is formed all the other champion requirements, as identified by Howell, naturally fall into place. CoInv will provide stimulus and constant learning opportunities as they will be built from other champions from all parts of the organisation, irrespective of discipline, functional unit, and organisational role. 
A CoInv would fulfil also Mumford et al's (2002) requirements for the generation of novel and useful ideas in a creative venture. They would provide the opportunity for intellectual stimulation as members of the community, being themselves ideas champions, would naturally support creative notions; they would provide the structure to permit those interested in innovation to become involved; and by their nature as a form of CoP, they would be given autonomy in their activities (and would be supported by the necessary resources to this end). CoInv provide the necessary ideas shelter and ideas formation resources, as part of their natural formation, and the opportunity for recognition of an individual's part in the process due to the natural equality within any CoP. Intrinsic motivation would be a character trait of those involved in such a community and people are most creative when they are motivated by interest, satisfaction and challenge. The presence of champions operating within these communities would inspire and stimulate.

A number of authors have identified that innovation champions are natural entrepreneurs (Beatty \& Gordon, 1991; Pinchot, 1985). Coulson-Thomas (2003) identifies the presence of Knowledge Entrepreneurs in an organisation as being those who innovate knowledge and knowledge sharing activities and this would also fit with the idea of innovation champions within a CoInv. Entrepreneurs (Ekvall, 1988) are individuals who seek freedom and Kets de Vries (1977) identifies them as being innovative. Champions will also have analytical and technical skills (Beatty \& Gordon, 1991), as well as knowledge both in the specific (and thus be knowledge entrepreneurs) but also in the generic (Chakrabarti, 1974) organisational situation and environment. This knowledge will come from experience as detailed above and is often a pre-requisite for innovation (Pearson, 1988). Innovation champions operate through strong social networks developed through this experience, and according to Jenssen \& Jorgensen, (2004) these networks may be decisive in developing the support for, and the championship of, the innovation. A champion's social network provides them with their power base (Beatty \& Gordon, 1991), and Krackhardt, (1992) argues that an innovation champion needs to maximise their social ties - both strong and weak - in order to succeed. The issue for organisations is how to discover these innovation champions and their social network to populate a CoInv and this is discussed below. 


\section{Identifying Innovation Champions and Mapping their Social Networks}

Identifying legitimately influential individuals, and visualizing the complexities of their relationship patterns have traditionally been difficult, time consuming, and expensive. Network Visualisation and Analysis (NVA) has been reported as an important new costeffective way to address this challenge (TLA, 2006). Its application to CoPs has been described (Smith, 2005b), and its application to the identification of influential individuals (opinion leaders) has also been detailed (Smith, 2005a). In NVA practice, data regarding individuals who seem to fulfil given descriptive identifying archetypes are collected from a target organisational community e.g. innovation champion archetype. These data are then analysed to produce lists of qualified individuals ordered by their influence.

Social Network Analysis (SNA) may also be applied to the data to suggest the relationships between organisational actors and to map their social networks, SNA is a very rich theoretical methodology that is only recently emerging as a practical and dynamic approach to real organisational problems (Kilduff \& Tsai, 2003), although the ability of SNA to reliably clarify the complex relationships between network agents has been questioned (Snowden, 2005). A number of simplified descriptive SNA texts exist, for example Scott (2000). Because of its highly mathematical nature, computers are typically used for calculation and display (Borgatti et al, 1999).

One of the practical NVA applications reported by TLA (2006) involved a major retail organisation with branches in a number of different cities that undertook to identify its most influential individuals with regard to (a) innovation, and (b) leadership. A further objective was to gain insight into the organisation-wide network of communications and trust-tagged relationships related to these themes.

In the study, email-delivered questions that relate to the above objectives were posed to all members of the three most senior management levels across all the company's locations and departments. The questions were based on archetypes describing relevant innovation and leadership identities. Members of the target community responded by picking, from a 
list displayed to them on a dedicated Internet site, the names of individuals that they had personally directly experienced as corresponding to the archetypes. The final response by the group to the questions was around $75 \%$.

The NVA identified a significant number of individuals demonstrating noteworthy innovation and leadership influence. Although there were names that appeared in both the innovation and leadership lists, significant differences overall were evident, indicating that innovation champions form a recognisable archetype; this supports our contention that they are not typically team leaders. This information was used in the case described to facilitate setting up steering groups and knowledge sharing communities on already existing trusttagged networks.

This approach requires further more rigorous research to substantiate its usefulness in identifying innovation champions and facilitating the formation of CoInv, but does seem to offer promising potential in this regard.

\section{Conclusions}

Innovation is essential to retain and improve organisations' market and competitive positions, and as such requires maximum internal support so that the current poor translation rate from idea to product is reduced. A community of innovation (CoInv) would greatly assist. In this paper we have argued that identifying champions of innovation will permit a CoInv network to be formed and that forming such a community will potentially trigger more innovations that are successfully supported.

We have argued, based on the literature cited, that innovation champions are special people, with a particular personality type and psychological profile. In order to succeed in championing innovations through the organisation, from idea and concept through to marketable product, they need not only procedural and resource support, but also social and cognitive support. We contend that this social support can be provided by a special type of CoP - a CoInv. We also contend that a CoInv provides important emotional support to 
champions and a fertile breeding ground for further innovations. It will also provide the shelter for knowledge entrepreneurs (Coulson-Thomas 2003) to develop and thus provide greater stakeholder value for the organisation.

Although rigorous empirical research studies are required, we suggest based on the TLA study described here, a means by which innovation champions may be identified, and it is our contention that once identified, these champions, with appropriate organizational support, will be motivated to form CoInv.

\section{References}

Adaman, F. and Devine, P. (2002), “A reconsideration of the theory of entrepreneurship: a participatory approach”, Review of Political Economy, Vol. 14, No, 3; pp. 329-355.

Amabile, T.M. (1988), “A model of creativity and innovation in organisations”, In Straw, B.M. and Cummings, L.L. (Eds.) Research in Organisational Behaviour, Vol. 10; pp. 123-167, JAI Press, Greenwich, CT.

Amit, R., Glosten, L. and Muller, E. (1993), "Challenges to theory development in entrepreneurship research", Journal of Management Studies, Vol. 30, No. 5; pp. 815-34.

Archilladelis B., Jervis P. and Roberston A. (1971), A Study of success and failure of industrial innovation, University of Sussex Press, Sussex.

Assimakopoulos D. and Yan J. (2005), "Social network analysis and communities of practice”, in Coakes, E. and Clarke, S. Encyclopedia of Communities of Practice in Information and Knowledge Management, Idea Group Reference, Hershey; pp. 474-480.

Beath, C.M. (1991), “Supporting the information technology champion”, MIS Quarterly, Vol. 15; pp. 355-372

Beatty, C.A. and Gordon J. (1991), "Preaching the gospel: the evangelist of new technology”, California Management Review, Vol. 33; pp. 73-94

Borgatti, S.P., Everett, M.G. and Freeman, L.C. (1999), UCINET 6.0 Version 1.00, Analytic Technologies, Natick. 
Brown, J.S. and Duguid, P. (1991), “Organisational learning and communities of practice: toward a unified view of working, learning and innovation”, Organisation Science, Vol. 2; pp. 40-57.

Chakrabarti, A.K. (1974), “The role of the champion in product innovation”, California Management Review, Vol. 17; pp. 58-62

Chakrabarti, A. K. and Hauschildt, J. (1989), "The division of labour in innovation management”, RandD Management, Vol. 19; pp. 161-171

Churchman, C.W. (1971), The Design of Inquiring Systems, Basic Book, New York

Coakes, E. and Clarke S. (2005), (Eds) Encyclopedia of Communities of Practice in Information and Knowledge Management, Idea Group Reference, Hershey.

Coulson-Thomas, C. (2003), The Knowledge Entrepreneu r, Kogan Page

Cross, R., Prusak, L. and Parker, A. (2001), "Knowing what we know: supporting knowledge creation and sharing in social networks”, Organizational Dynamics, Vol. 30, No. 2; pp. 100-120.

Day, D.L. (1994), "Raising radicals: Different processes for championing innovative corporate ventures”, Organisation Science, Vol. 5; pp. 148-172

Drazin, R., Glynn, M.A. and Kazanjian, K. (1999), "Multilevel theorising about creativity in organisations”, The Academy of Management Review, Vol. 24, No. 2; pp. 286-307.

Ekvall, G. (1988), Fornyelse och Friktion. Om Organisation, Kreativitet og Innovation Centraltryckeriet AB.

Etzioni, A. (1961), A Comparative Analysis of Complex Organisations, Free Press, New York.

Felkins, P.K., Chakiris, B.J. and Chakiris, K.N. (1993), Change Management: a Model for affective organisational performance, White Plains, NY: Quality Resources

Glynn, M.A. (1996), "Innovative genius: a framework for relating individual and organisational intelligences to innovation”, Academy of Management Review, Vol. 21, No. 4; pp. 1081-1111.

Hargadon, A. (2003), How Breakthroughs Happen, Harvard Business School Press, Boston, MA.

Holbeck, J. (1990), “Lokale innovasjonstiltak: Padrivers plass som ildsjel og integrator”. in Ledelse of Innovasjorn I Kommunene, H. Balersheim (ed); pp. 142-167, Oslo: Tano 
Howell, J.M. (2005), “The right stuff: identifying and developing effective champions of innovation”, Academy of Management Executive, Vol. 19, No. 2; pp. 108-119.

Howell, J.M. and Bois, K. (2004), “Champions of technological innovation: the influence of contextual knowledge, role orientation, idea generation and idea promotion on champion emergence”, The Leadership Quarterly, Vol. 15; pp. 123-43.

Howell, J.M. and Higgins, C.A. (1990), “Champions of Technological Innovation”, Administrative Science Quarterly, Vol. 35; pp. 315-41.

Jenssen, J.I. and Jorgensen, G. (2004), "How do Corporate Champions Promote Innovations?’ International Journal of Innovation Management, Vol. 8 No. 1; pp. 6386

Kanter, R.M. (1983), The Change Masters, Simon and Schuster, New York.

Kets de Vries, M.F.R. (1977), “The entrepreneurial personality: a person at the crossroads”, Journal of Management Studies, Vol. 14; pp. 34-37

Kautz, K. and Larsen, E.A (2000), “Diffusion theory and practice: Disseminating quality management and software process improvement innovations”, Information Technology and People, Vol. 13, No. 1; pp. 11-26.

Kilduff, M. and Tsai, W. (2003), Social Networks and Organisations, Sage, London.

Koudal, P. and Coleman, G.C., (2005), "Coordinating operations to enhance innovation in the global corporation”, Strategy and Leadership, Vol. 33, No. 4; pp. 20 - 32

Krackhardt, D. (1992), "The strength of strong ties: The importance of philos in organisations”, in Networks and Organisations. Structure Form and Action, N. Nohria and R.G., Eccles (eds); pp. 216-239, Mass: Harvard Business School

Krause, D. (2004), "Influence -based leadership as a detriment of the inclination to innovate and of innovative-related behaviours”, The Leadership Quarterly, Vol. 15; pp. 499-529.

Lagace, M. (2005), "How to Put Meaning Back into Leading - an interview with J.M. Podolny”, R. Khurana \& M. Hill-Popper; retrieved April 132005 from Harvard Business School, Working Knowledge

http://hbswk.hbs.edu/tools/print_item.jhtml?id=4563\&t=finance

Lehaney, B., Clarke, S., Coakes, E., and Jack, G., (2004) Beyond Knowledge Management Hershey: Idea Group Publishing 
Leonard-Barton, D. and Sensiper, S. (1998), "The role of tacit knowledge in group innovation”, California Management Review, Vol. 40, No. 3; pp. 112-132.

Lesser, E.L. and Storck, J. (2001), "Communities of practice and organisational performance”, Knowledge Management, Vol. 40, No. 4; retrieved February 16, 2006: http://www.research.ibm.com/journal/sj/404/lesser.html

Markham, S.K. (1998), “A longitudinal study of how champions influence others to support their projects”, Journal of Product Innovation Management, Vol. 15; pp. 490504

McFadzean, E., O’Loughlin, A. and Shaw, E. (2005), “Corporate entrepreneurship and innovation part 1: the missing link”, European Journal of Innovation Management, Vol. 8, No. 3; pp. 350 - 372.

Melcrum (2006), Pederson citing Business Horizons March/April 1996 retrieved January 16 , 2006 http://www.km-review.com/cgibin/melcrum/eu_content.pl?docurl=article\%20km\%20cat

Moss Kanter, R. (1988), “When a thousand flowers bloom: structural, collective, and social conditions for innovation in organisations”, Research in Organisational Behaviour, Vol. 10; pp. 169-211.

Mumford, M.D. and Licuanan, B. (2004), "Leading for innovation: conclusions, issues and directions”, The Leadership Quarterly, Vol. 15; pp. 163-171.

Mumford, M.D., Scott, G.M., Gaddis B. and Strange J.M. (2002), "Leading creative people: orchestrating expertise and relationships”, The Leadership Quarterly, Vol. 13; pp. 705-750.

Nahapiet, J. and Ghoshal, S (1998), "Social capital, individual capital and the organisational advantage”, Academy of Management Review, Vol.23, No.2; pp. 242-266.

Oberg, W. (1972), “Charisma, commitment and contemporary organisation theory”, MSU Business Topics, Vol. 20; pp. 18-32.

Parker, S.K. and Axtel, C.M. (2001), "Seeing another viewpoint: antecedents and outcomes of employee perspective taking”, Academy of Management Journal, Vol. 44, No. 6, pp. 1085-1101.

Pearson, A.E., (1988) “Tough-minded ways to get innovative” Harvard Business Review Vol. 66; pp. 99-106 
Pinchot, G. (1985), Intrapreneuring: Why you Don't Have to Leave the Corporation to Become and Entrepreneur, Harper and Row: New York.

Rogers, E.M. (1995), Diffusion of Innovation, 4th Edition, Free Press, New York, NY.

Schön, D.A. (1965), “Champions for radical new inventions”, Harvard Business Review, Vol. 41; pp. 77-86.

Scott, J. (2000), Social Network Analysis, Sage, London, UK

Shaw, E., O'Loughlin, A. and McFadzean, E. (2005), "Corporate entrepreneurship and innovation part 2: a role- and process-based approach”, European Journal of Innovation Management, Vol. 8, No. 4; pp. 393 - 408.

Schenkel, A., Teigland, R. and Borgatti, S.P. (2001), "Theorizing structural properties of communities of practice: a social network approach”, paper presented at Academy of Management annual conference.

Slater, S.F. and Narver, J.C. (1995), "Market orientation and the learning organisation”, Journal of Marketing, Vol. 59; pp 63-74

Smith, P.A.C. (2005a), "Knowledge sharing and strategic capital: the importance and identification of opinion leaders”, The Learning Organization, Vol. 12, No. 6, Special Issue: “Knowledge Sharing”; pp. 563 - 574.

Smith, P.A.C. (2005b), ”Organisational change elements of establishing, facilitating, and supporting CoPs”, in Coakes, E. and Clarke, C. (Eds), Encyclopedia of Communities of Practice in Information and Knowledge Management, idea Group Reference, London; pp. $400-406$.

Snowden, D. (2005), "From atomism to networks in social systems", The Learning Organization, Vol. 12, No. 6, Special Issue: “Knowledge Sharing”; pp. 552 - 562.

Stacey, R.D. (2001), Complex Responsive Processes in Organizations: Learning and Knowledge Creation, Routledge, London.

Stata, R. (1989), “Organisational learning: the key to management innovation”, Sloan Management Review, Vol. 30, No. 3; pp. 63-74.

Sullivan, P. (1998), Profiting from intellectual capital: Extracting value from innovation, John Wiley and Sons inc, New York. 
Teece, D.J. (1998), “Capturing value from knowledge assets: the new economy, markets for know-how and intangible assets”, California Management Review, Vol. 40, No. 3; pp. 55-79.

Thornberry, N. (2001), “Corporate entrepreneurship: antidote or oxymoron?” European Management Journal, Vol. 19, No. 5; pp. 526-533.

Tidd, J. (2001), "Innovation management in context: environment, organization and performance”, International Journal of Management Review, Vol. 3; pp. 169-183.

TLA (2006), Case Studies 1 - 5; retrieved February 16, 2006: www.tlainc.com

Tushman, M.L. and Nadler D. (1986), “Organizing for innovation”, Californian Management Review, Vol. 28, No. 3; pp. 74-92.

Van de Ven, A.H.C. (1986), "Central problems in the management of innovation”, Management Science, Vol. 32; pp. 590-607.

Wenger, E. (1998), Communities of Practice: Learning, Meaning and Identity Cambridge: Cambridge University Press.

Wenger, E. (2001), Retrieved April 2004: http://www.ewenger.com/

Wenger, E., McDermott, R. and Snyder, W.M. (2002), Cultivating Communities of Practice, Harvard Business School Press, Cambridge, MA.

Zahra, S.A. (1985), "Corporate entrepreneurship and financial performance: the case of management leveraged buyouts”, Journal of Business Venturing, Vol. 10, No. 3; pp. 225-247. 